\title{
Taxonomic review of Costa Rican Pipunculidae (Insecta: Diptera)
}

\author{
J. A. Rafael and M. D. da S. Menezes \\ Instituto Nacional de Pesquisas da Amazônia (INPA), Caixa Postal 478, CEP 69011-970, Manaus, Amazonas, Brazil. \\ E-mail: jarafael@inpa.gov.br
}

Received 16-VI-1998. Corrected 18-I-1999. Accepted 2-II-1999.

\begin{abstract}
Twenty nine species and ten genera of Pipunculidae are reported from Costa Rica, including eight previously recorded species, thirteen new species and eight new records. The following species are described and illustrated: Cephalosphaera guanacastensis, C. procera, C. zumbadoi, Eudorylas abnormalis, E. echinatus, E. falx, E. moragai, E. serratus, Elmohardyia adunca, E. bifida, E. costaricana, E. galeata and E. maculata. The new records are Chalarus connexus Rafael, Parapipunculus elegantulus (Williston), Cephalosphaera jamaicensis (Johnson), C. macroctenia Rafael, C. panamaensis Hardy, Microcephalops williamsi (Hardy), Eudorylas vidali Rafael and Basileunculus rex (Curran). Parapipunculus elegantulus (Williston) is redescribed from the holotype. The previously unknown females of P. elegantulus and $C$. jamaicensis are described. All Costa Rican species are listed. Keys to the species of Cephalosphaera Enderlein and Elmohardyia Rafael are presented.
\end{abstract}

Key words: Costa Rica, Diptera, Pipunculidae, Taxonomy.

Pipunculidae are closely related to the Syrphidae. Together they are grouped in the Syrphoidea, sister group of Schizophora (Cumming et al., 1995). The phylogeny and classification of Pipunculidae were proposed by Rafael \& De Meyer (1992). The Neotropical species have been revised by the senior author since 1986 and all papers concerning the fauna from Mexico, Central America and West Indies are referred by Rafael (1996) and along this paper. This family was poorly represented in the Costa Rican fauna, with the following eight recorded species by De Meyer (1996) in his world catalogue: Eudorylas cinctus subtilis (Hardy), E. willistoni (Kertész), Metadorylas spinosus (Hardy), Elmohardyia arnaudi Rafael, E. gowdeyi (Curran), Tomosvaryella lynchi (Shannon), T. tuberculata Hardy and T. subvirescens (Loew). Besides the previously recorded species, this study revealed thirteen undescribed species and new distribution records for eight more species.
The small studied collection of the Instituto Nacional de Biodiversidad (INBio), showed high diversity of pipunculid species. It is inevitable that additional species and records will be found when more collections are made.

\section{MATERIALS AND METHODS}

A short diagnoses precedes each species description. Descriptions of new species are nlade from the holotype and the opposite sex from the paratype. One wing and male terminalia were studied by removing them from the holotype, after which the wing was mounted on a microslide with balsam and the terminalia was placed in a microvial with glycerin and both pinned along with the specimen. Primary types are deposited in the collections of the Instituto Nacional de Biodiversidad (INBio), Santo Domingo, Costa Rica and paratypes and other specimens have been deposited at INBio 
and at Instituto Nacional de Pesquisas da Amazônia (INPA), Manaus, Brazil.

The generic classification adopted here follows Rafael \& De Meyer (1992). The following is primarily a taxonomic study and should provide a foundation for future systematic research.

Female specimens not associated with males were not identified. Terminology is based on McAlpine (1981) except for those specific pipunculid structures that were labeled according to Rafael (1987). Abbreviations used in the text are: $\mathrm{BL}=$ bar label, $\mathrm{F}=$ female, Fig. = figure, $h t=$ holotype, $\mathrm{pt}=$ paratype, $\mathrm{lv}=$ lateral view, $\mathrm{vv}=$ ventral view, $\mathrm{dv}=$ dorsal view; LN = Lambert North, LS = Lambert South (these are coordinates in the 1: 50,000 topographic map of Costa Rica).

The climate and vegetation of Costa Rica have been discussed by Murillo \& Zeledon (1985), Boza \& Mendoza (1981), Gomez (1986), Herrera (1986), Stiles \& Skutch (1989), Gauld (1997) and details are not repeated here.

In order to save space codes are used, under Material, only for repetitive specimens collected at Estación Pitilla; San Luis, Monteverde; Estación Las Pailas and Estación Sirena:

Code 1: COSTA RICA, Estación Pitilla, 9 km South Santa Cecilia, Parque Nacional Guanacaste, Provincia Guanacaste, 700 m, LN 330200-380200;

Code 2: COSTA RICA, San Luis, Monteverde, Provincia Puntarenas, 1000-1350 m, LN 449250-250850;

Code 3: COSTA RICA, Estación Las Pailas, Parque Nacional Rincón de La Vieja, Provincia Guanacaste, 8001000 m, LN 306300-388600;

Code 4: COSTA RICA, Estación Sirena, Parque Nacional Corcovado, Provincia Puntarenas, 0-100 m, LS 270500-508300.

The information between brackets, under Material, contains data not included on the labels.

Genera occurring in Costa Rica can be keyed using Rafael (1996).

\section{RESULTS}

\section{Genus Chalarus Walker}

This genus is cosmopolitan. The Neotropical species were revised and keyed by Rafael (1990a). The West Indian species were keyed by Rafael (1996).

\section{Chalarus connexus Rafael}

Chalarus connexus Rafael, 1988a: 6

C. connexus, described from Brazil and Trinidad, is the only Chalarus species that has been recorded from Costa Rica. It is easily identified by having the cell r1 closed. There are at least two more species but they cannot be identified at the specific level because there are no male specimens associated with females.

Material. Code 1, May 1994, P. Rios, Malaise, \# 2896, BL CRI001 878718 (1 M INBio); Code 1, Jul 1994, C. Moraga, \# 3158, BL CRI002 001359 (1 M INPA).

\section{Genus Parapipunculus Rafael}

This small genus is distributed mainly in the Nearctic Region and the four species were keyed by Rafael (1986). Subsequently, De Meyer (1989) transferred $P$. appendiculatus to the genus Cephalops.

\section{Parapipunculus elegantulus (Williston)}

(Figs. 1-8, 118)

Pipunculus elegantulus Williston, 1892: 87; Cresson, 1911: 296.

Cephalosphaera elegantula; Hardy, 1943: 50; Aczél, 1948: 26, 73; 1952: 240. 1966: 2

Pipunculus (Cephalosphaera) elegantula; Hardy,

Parapipunculus elegantulus; Rafael, 1986: 421.

This species has not been revised in the previous pipunculid papers of the senior author so the subsequent citation is given above. This is the only Neotropical species of the genus, described originally from Mexico, and the record in Costa Rica is the most southerly. It was known only from the male holotype, redescribed below. One female sharing some characters of the male characters belongs here and it is being described below.

Redescription (holotype male). Body length $4.5 \mathrm{~mm}$; wing $5.3 \mathrm{~mm}$. Eyes contiguous on frons for a distance slightly greater than length of frontal triangle. Front and face silvery gray pruinose. Scape and pedicel brown, flagellum rounded below, brown with yellow margin. Scutum and scutellum densely bristled, 
subshining black, sparsely brown pruinose. Notopleuron gray pruinose, densely bristled. Postpronotal lobe yellow. Propleural fan with whitish bristles. Mesopleuron and postnotum black, gray pruinose. Legs yellow, except coxae dark brown to black; femora dark brown to black medially and distal tarsomeres brown; hind trochanter with slender ventral bristles; all femora with ventral ctenidium and hind femur with posterior row of short black bristles and a pair of subapical anterior and posterior black bristles; tibiae without apical bristles and hind tibia with two erect posterior bristles. Wing (Fig. 118) with vein $\mathrm{r}-\mathrm{m}$ placed near basal fourth of cell dm; vein M2 short. Halter yellow. Abdomen (Fig. 1, 2) densely bristled, shining black with gray pruinosity on tergite 1 and laterally on tergites 2-5 with pruinescence triangularly produced on each tergite posteriorly. Syntergosternite 8 about equal to the length of tergite 5 , slightly inclined to the right, with a small membranous area distally. Epandrium and surstylus (Fig. 3) yellow. Surstylus (Figs. 4-5) asymmetrical. Paramere and aedeagus as in Fig. 6. Ejaculatory apodeme as in Fig. 7.

Female. Body length $4.6 \mathrm{~mm}$; wing 4.9 $\mathrm{mm}$. Frons entirely silvery gray pruinose. Pedicel yellow to brown, flagellum yellow. Femora yellow with small black spot on anterior side; hind femur without posterior row of black spines, either subapical or posterior bristles; hind tibia without erect posterior bristles medially. In other respects as in male. Terminalia (Fig. 8) mainly yellow except syntergosternite $7+8$ partially shining black dorsally, slightly shorter than ovipositor; the latter slightly curved outward.

Material. MEXICO, Guerrero, Chilpancingo, 4.600 $\mathrm{ft}$, June, H. H. Smith (ht M, Natural History Museum, London; right wing partially damaged); Code 1, 9-20 Ene 1994, P. Rios, \# 2561, BL CRI001 844273 (1F INBio).

\section{Genus Cephalosphaera Enderlein}

The Neotropical species were revised and keyed by Rafael (1992). Two recently created subgenera by De Meyer (1994) were keyed by Rafael (1996) and both occur in Costa Rica.

A Key to Costa Rican species, based on males, is as follows.

1. -Syntergosternite 8 divided by membranous area dorsally and ventrally (Fig. 35).

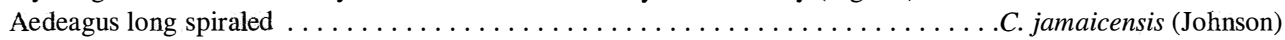

- Syntergosternite 8 not divided by membranous area (Fig. 25) $\ldots \ldots \ldots \ldots \ldots \ldots \ldots \ldots \ldots \ldots \ldots \ldots \ldots \ldots \ldots \ldots \ldots$

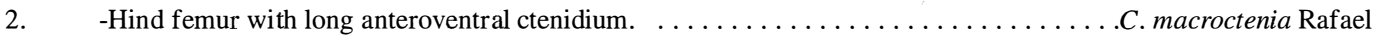
- Hind femur with short anteroventral ctenidium, subequal the ctenidium of fore and mid femora. . . . . . . . 3

3. -Surstylus slender, distinctly longer than epandrium (Fig. 26). Femora partially dark brown to black, mainly hind

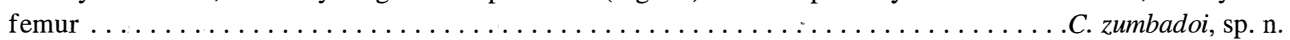
- Surstylus shorter or subequal to length of epandrium (Fig. 19) $\ldots \ldots \ldots \ldots \ldots \ldots \ldots \ldots \ldots \ldots \ldots$

4. -Abdomen parallel sided, about 2.5 times longer than wide (Fig. 18), rather yellow laterally and posterolaterally. Aedeagus slender and long with three apical rami (Fig. 23) .................. procera, sp. n. - Abdomen rather oval, less than 2.0 times longer than wide (Fig. 9) with gray pruinescence on tergite 1 and posterolaterally on tergite 5 in dorsal view. Aedeagus apparently with 5 apical rami (Figs. 15, 16) $\ldots \ldots \ldots \ldots 5$

5. -Surstylus pointed distally (Fig. 10). Hind tibia without erect posterior bristles medially C. guanacastensis, sp. n. - Surstylus rounded distally. Hind tibia with erect posterior bristles medially ......... . panamaensis Hardy

\section{Cephalosphaera (Cephalosphaera) guanacastensis, sp. n.}

(Figs. 9-17, 119)

Diagnoses. Legs mainly yellow. Scutellum concolorous with scutum. Abdomen with gray pruinosity on distal half of tergite 1 and posterolaterally on tergite 5 . Syntergosternite 8 shorter than tergite 5 , not divided by membranous area. Surstylus almost symmetrical. 
Description (male only, female unknown). Wing $6.0 \mathrm{~mm}$. Head lost. Scutum, postpronotal lobe and scutellum dark brown to black, brown pruinose. Notopleuron, mesopleuron, subscutellum and laterotergite gray pruinose. Scutellum with two black spine-like bristles at posterior margin. Legs yellow, except mid and hind coxa and fifth tarsomere brown; hind tibia without erect posterior bristles medially. Wing (Fig. 119) hyaline; base with two strong short black spines; section between cell $\mathrm{dm}$ and vein M1 longer than vein dm-cu, the latter slightly sinuous. Halter yellow, with small dark spot on knob. Abdomen (Fig. 9) dark brown to black, subshining, brown pruinose with gray pruinosity on distal half of tergite 1 and posterolaterally on tergite 5. Syntergosternite 8 dark brown to black, shorter than tergite 5, with membranous area distally. Epandrium dark brown to black and surstylus yellow. Surstylus (Fig. 10) subsymmetrical; in lateral view as in Figs. 11-12. Paramere and aedeagus as in Figs. 13-16. Paramere with short subapical lateral projection. Aedeagus with two additional branches, giving the false impression of being five branched. Ejaculatory apodeme as in Fig. 17.

Material. Code 1, Ene 1994, C. Moraga, \# 2563, BL CRI001 828733 (ht M, head lost; INBio).

Etymology. The specific name refers to Guanacaste Province where the specimen was collected.

Remarks. C. guanacastensis runs to the couplet of $C$. panamaensis and C. boutropis in the key of Rafael (1992). From the Argentinean $C$. boutropis it differs by having syntergosternite 8 not being divided by a membranous area; from panamaensis it differs by the following: scutellum with two black bristles at the margin, hind tibia without erect posterior bristles medially and paramere with a subapical lateral projection.

\section{Cephalosphaera (Cephalosphaera) procera, sp. $n$.}

(Figs. 18-24, 120)

Diagnoses. Antenna, postpronotal lobe, legs and halter yellow; flagellum short acute. Abdomen partially yellow to light brown. Surstylus subsymmetrical, shorter than epandrium. Aedeagus thin and very elongated.
Description (male only, female unknown). Body length $6.3 \mathrm{~mm}$; wing $6.9 \mathrm{~mm}$. Eyes contiguous on frons for a distance slightly greater than length of frontal triangle. Frontal triangle and face silvery gray pubescent. Antenna yellow, flagellum short acute. Scutum dark brown to black, brown pruinose. Scutellum brown with small bristles laterally. Postpronotal lobe yellow. Notopleuron gray pruinose. Mesopleuron light brown, sparsely brown pruinose, except proepisternum and anterior region of the anepisternum black, sparsely gray pruinose. Subscutellum and laterotergite gray pruinose in posterior view. Legs yellow except mid and hind coxa, apices of mid and hind femur and distal tarsomeres brown. Hind tibia without erect posterior bristles medially. Wing (Fig. 120) hyaline with two strong short bristles at base; third costal section about 1.2 times as long as fourth; section between cell dm and vein M2 longer than vein dm-cu. Halter yellow. Abdomen (Fig. 18) rather parallel sided. Tergite 1 with 4-5 longer bristles laterally, opaque brown to black on bases of tergites 2-5, this color being larger on posterior tergites and subshining, rather yellow to light brown on all of tergite 1 and on lateral and posterior margins of posterior tergites, being these yellow regions gray pruinose in posterior view. Tergite 5 longer than tergite 4 . Syntegosternite 8 dark brown to black, shorter than tergite 5, with distal membranous area. Epandrium and surstylus (Fig. 19) brown. Surstylus subsymmetrical, in lateral view as in Fig. 20-21. Paramere as in Fig. 22. Aedeagus (Fig. 23) thin and elongated. Ejaculatory apodeme as in Fig. 24.

Material. COSTA RICA, Fila Matahambre, F[in]ca La Purruja, Cerro La Torre, Pen[insula] Osa, Prov[incia] Punta[renas], 200 m, May 1994, J. F. Quesada, LN 277000-527000, \# 2922, BL CRI001 964775 (ht M, INBio).

Etymology. The specific name refers to the elongated abdomen (from Latin procerus = long).

Remarks. C. procera runs to $C$. panamaensis in the key of Rafael (1992). It differs by the entirely yellow antenna, hind tibia without erect posterior bristles medially, a large pair of light brown spot on all tergites, surstylus 

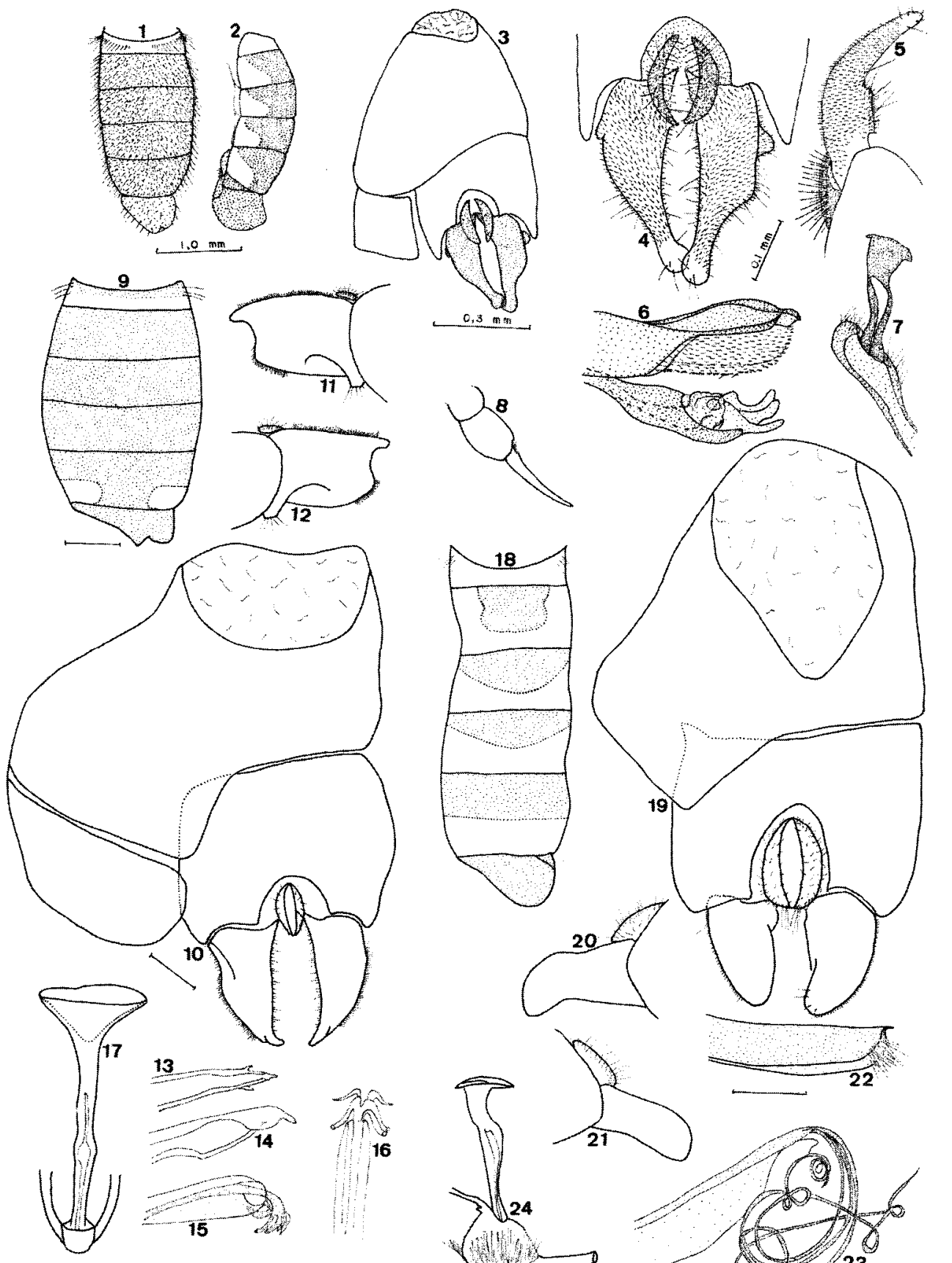
shorter than epandrium, aedeagus thin and elongated, and paramere bristled distally. $C$. panamaensis has the pedicel brown, flagellum yellow, hind tibia with erect posterior bristles medially, no yellow or light brown coloration on the abdomen, surstylus about equal to the length of epandrium, aedeagus short and paramere not bristled at apex.

\section{Cephalosphaera (Cephalosphaera) zumbadoi, sp. $\mathrm{n}$.}

(Figs. 25-32, 121)

Diagnoses. Scape and pedicel black, flagellum yellow, long acute. All femora black medially, hind femur shining black on posterior side. Scutellum with two short black bristles at margin. Tergite 1 without long bristles. Syntergosternite 8 shorter than tergite 5 . Surstylus elongated. Aedeagus with small projection dorsally.

Description (male only, female unknown). Body length $4.6 \mathrm{~mm}$, wing $5.8 \mathrm{~mm}$. Junction of compound eyes about as long as frontal triangle. Frontal triangle and face silvery gray pubescent. Scape and pedicel dark brown to black; flagellum yellow with apex long acute. Scutum and scutellum dark brown to black, brown pruinose. Notopleuron gray pruinose. Postpronotal lobe yellow. Propleuron black. Mesopleuron partially black on anepisternum, sparsely gray pruinose on black coloration. Scutellum with two black bristles at posterior margin. Subscutellum and laterotergite dark brown to black, gray pruinose. Legs with all coxae brown and all femora dark brown to black, except wide bases and narrow apices yellow. Hind femur with ventral ctenidium larger than anterior ones, shining black on posterior and on ventral side. Wing (Fig. 121) hyaline with two black spines at base; third costal section nearly two times longer than fourth. Section between cell $\mathrm{dm}$ and vein M2 longer than vein dm-cu. Halter yellow with small dark spot on knob. Abdomen (Fig. 25) dark brown to black, gray pruinose on tergite 1 and posterolaterally on tergite 5 . Tergite 1 without strong bristles laterally. Syntergosternite 8 about one third shorter than length of tergite 5 , with dis- tal membranous area. Epandrium brown and surstylus yellow. Surstylus (Fig. 26) subsymmetrical, elongated; in lateral view as in Figs. 27-28. Paramere and aedeagus as in Figs. 2931. Paramere with distal projection and aedeagus short ramified, with small bifid projection dorsally. Ejaculatory apodeme as in Fig. 32.

Material. COSTA RICA, Fila Casa Loma, [Peninsula] Osa, Prov[incia] Punta[renas], 200-500 m, 28 Dic 1993, M. Zumbado, LS 514300-296300, \# 2668, BL CRI001 725975 (ht M, INBio).

Etymology. The specific name is in honor of Mr. Manuel Zumbado who collected the specimen described here.

Remarks. C. zumbadoi is most closely related to C. mocaensis, from Dominican Republic, and it runs to couplet this species in couplet 8 in the key of Rafael (1992). It can be separated only by characters of the terminalia, namely: surstylus more elongated and slender and aedeagus with small bifid projection dorsally.

\section{Cephalosphaera (Cephalosphaera) macroctenia Rafael}

(Figs. 33-34)

Cephalosphaera macroctenia Rafael, 1992: 641.

This species was described from the State of Pará, Brazil. The Costa Rican specimen represents the first record subsequent to its original description. One male specimen is conspecific, except that the paramere (Figs. 33-34) is slightly different from those represented in the original description.

Material. Code 2, Feb 1994, Z. Fuentes, \# 2615, BL CRI001 962287 (1 M, INBio).

\section{Cephalosphaera (Cephalosphaera) panamaensis Hardy}

Cephalosphaera panamaensis Hardy, 1948a: 8.

According to Rafael (1996) the Panamanian female specimen was originally incorrectly associated with the male; to date, this male has no associated female. Here, two males were identified.

Material. Code 1, Jul 1994, C. Moraga, \# 3158, BL CRI002 001475 (1 M, INBio); Code 4, A. G. Fonseca, Jun 1991, BL CRI000 670783 (1 M, INPA). 


\section{Cephalosphaera (Neocephalosphaera) jamaicensis (Johnson)}

(Figs. 35-37)

Pipunculus jamaicensis Johnson, 1919: 433.

This is the first record subsequent to its original description from the Jamaica. The male specimen from Costa Rica differs from Jamaican specimen by having the flagellum and legs mainly yellow (mainly brown in the Jamaican specimen), the third costal section is as long as the fourth (longer in the Jamaican specimen) and abdomen (Fig. 35) brown pruinose on all of tergites 1-2 and across posterior margin of tergites 3-5, more so on tergite 5 (tergite 2 not entirely brown pruinose, being opaque black at base in Jamaican specimen).

The following is the first description of the female: Body $4.4 \mathrm{~mm}$; wing $5.6 \mathrm{~mm}$. Frons and face silvery gray pruinose. Antenna entirely yellow, flagellum long acute. Legs yellow, except coxae and distal tarsomeres brown. Abdomen (Fig. 36) dark brown to black, sparsely gray pruinose dorsally on tergite 2 and laterally on all tergites. In others respects as in original description of male. Terminalia (Fig. 37) with syntergosternite $7+8$ brown, shorter than ovipositor, the latter yellow, curved outward.

Material. Code 4, A. G. Fonseca, Jun 1991, BL CRI000 670783 (1 F, INBio); Code 3, 17-23 Jul 1993, K. Taylor, \# 2238, BL CRI001 133169 (1 M, INBio)

\section{Cephalosphaera spp.}

Four female specimens were not associated with any male and cannot be identified to species. Two different females have a straight ovipositor equal to the length of the syntergosternite. The other two female specimens have a straight ovipositor that is longer than syntergosternite. All specimens are deposited at INBio.

\section{Genus Cephalops Fallén}

The Neotropical species were revised and keyed by Rafael (1991). Recently De Meyer (1994) created four subgenera. The two subgenera occurring in the New World were keyed by Rafael (1996).

\section{Cephalops spp.}

Six female specimens representing at least two different species were not associated with males and cannot be identified Four females have antenna brown, legs black, third costal section 1.5 times longer than fourth section and abdomen dark brown to black with gray pruinosity on tergites $1-2$. Two females have antenna and legs entirely yellow and abdomen partially yellow. All specimens are deposited at INBio.

\section{Genus Microcephalops De Meyer}

The Neotropical species were revised by Rafael (1991) under the name Cephalops, group latifrons, and latter transferred to the genus Microcephalops by Rafael (1996).

\section{Microcephalops williamsi (Hardy)}

Dorilas (Dorilas) williamsi Hardy, 1954: 54.

This species is widespread across the Neotropical Region (Rafael, 1996), being recorded in Brazil, Colombia, Dominican Republic and now in Costa Rica.

Material. Code 1, 6-17 Set 1993. C. Moraga, \# 2344, BL CRI001 614789 (1 M, INBio); Ene 1994, C. Moraga, \# 2563, BL CRI001 828751 (1 F, INBio); Jun 1994, P. Rios, \# 2996, BL CRI001 883789 (1 F, INPA).

\section{Microcephalops spp.}

Three female specimens representing two different species and not associated with males cannot be identified. They present different pattern of coloration and different ovipositor shape. All specimens are deposited at INBio.

\section{Genus Eudorylas Aczél}

The eleven previously recorded Mexican and Central American species were studied but not keyed by Rafael (1993). It is the largest genus of the family and contains very heterogeneous species. In light of present knowledge it is premature to present a key to Costa Rican species because we believe many more species remain undiscovered and the key would soon be obsolete. The eight Costa Rican species can be separated by the short diagnoses and figures presented here and by Rafael (1993). 
Eudorylas abnormalis, sp. n.

(Figs. 38-43, 122)

Diagnoses. Antenna dark brown to black, flagellum acute. Third costal section as long as fourth. Legs yellow, except coxae black and femora black dorsally. Tergite 6 visible dorsally. Outer side of epandrium protracted.

Description (male only, female unknown). Body length $5.1 \mathrm{~mm}$; wing $5.7 \mathrm{~mm}$. Eyes contiguous on frons for a distance greater than length of frontal triangle. Frontal triangle and face gray pruinose. Antenna dark brown to black, flagellum acute. Thorax dark brown to black with scutum, scutellum and postpronotal lobe brown pruinose. Notopleuron partially, mesopleuron, subscutellum and laterotergite gray pruinose. Legs yellow, except coxae dark brown to black on dorsal half and tarsi dark brown to black. Midfemur with ventral ctenidium. Tibia without distinct bristles, either distally or medially. Wing (Fig. 122) with third costal section as long as fourth; vein r-m placed near basal third of cell dm; vein M1 slightly sinuous; vein $\mathrm{dm}$-cu straight, as long as vein $\mathrm{CuA1}$. Halter with stem brown, knob black. Abdomen (Fig. 38) dark brown to black with gray pruinosity on all tergite 1 and posterolaterally on tergites $2-5$. Syntergosternite 8 brown pruinose, shorter than tergite 5 , with distal membranous area. Epandrium and surstylus (Fig. 39) brown to black. Epandrium protracted on outer side. Surstylus asymmetrical, being the inner longer than outer surstylus; in lateral view as in Figs. 40-41. Paramere and aedeagus as in Fig. 42. Aedeagus simple. Ejaculatory apodeme as in Fig. 43.

Material. COSTA RICA, F[in]ca Génesis II, A[rea] Clonservacion] Amistad, Prov[incia] Carta[go], $2300 \mathrm{~m}$, 9-10 Jun 1994, M. A. Zumbado, LN 188600-545900, \# 2918, BL CRI001 964519 (ht M, INBio).

Etymology. The specific name refers to the unusual characters that this species presents. See remarks below (from Latin abnormalis $=$ unusual).

Remarks. This species differs from other species of Eudorylas by characters unusual in the genus, namely: tergite 6 visible dorsally, epandrium projecting laterally and aedeagus without apical rami.

\section{Eudorylas cinctus (Banks) \\ Pipunculus cinctus Banks, 1915: 169.}

This species has been treated as two subspecies: E. c. cinctus and E. c. subtilis (Hardy). The first one has been recorded in USA, Mexico and now in Costa Rica. The second one has been recorded in USA, Mexico and Costa Rica (De Meyer, 1996). The two taxa therefore appear to be sympatric and the subspecific status within this species is no more considered.

Material. COSTA RICA, Monumento Nacional Guayabo, A[rea] C[onservación] Amistad, Prov[incia] Carta[go], 1100 m, Jun 1994, C. Fonseca, LN 217400-570000, \# 2989, BL CRI001 881465 (1 M, INBio).

\section{Eudorylas echinatus, sp. $\mathrm{n}$.}

(Figs. 44-52, 123)

Diagnoses. Antenna and legs mainly black. Third costal section slightly shorter than fourth. Syntergosternite 8 shorter than tergite 5 , with distal membranous area.

Description (male). Body length $3.9 \mathrm{~mm}$; wing $4.4 \mathrm{~mm}$. Junction of compound eyes shorter than length of frontal triangle; the latter black, sub-shining medially, brown pruinose in frontal view, gray in dorsal view. Face gray pruinose. Thorax dark brown to black with scutum and scutellum brown pruinose. Notopleuron, postpronotal lobe, mesopleuron, subscutellum and laterotergite gray pruinose. Legs black, except apices of femora and bases of tibiae yellow. All femora with ventral ctenidium, inconspicuous on fore and hind pair. Tibiae without distinct bristles either distally or medially. Wing (Fig. 123) hyaline with third costal section slightly shorter than fourth; vein $\mathrm{r}-\mathrm{m}$ placed near basal two fifths of cell $\mathrm{dm}$. Halter with stem chestnut, knob black. Abdomen (Fig. 44) dark brown to black with 4-5 lateral bristles on tergite 1 and gray pruinescence on tergite 1 and posterolaterally on tergites $2-5$, more so on tergite 5 . Syntergosternite 8 sparsely brown pruinose, shorter than tergite 5 , with apical membranous area. Epandrium and surstylus (Fig. 45) black. Surstylus subsymmetrical, downcurved distally; in lateral view as in Figs. 46-47. Paramere as in Fig. 48. Aedeagus (Fig. 49) short ramified, each rami with small recurved spines. Ejaculatory apodeme 


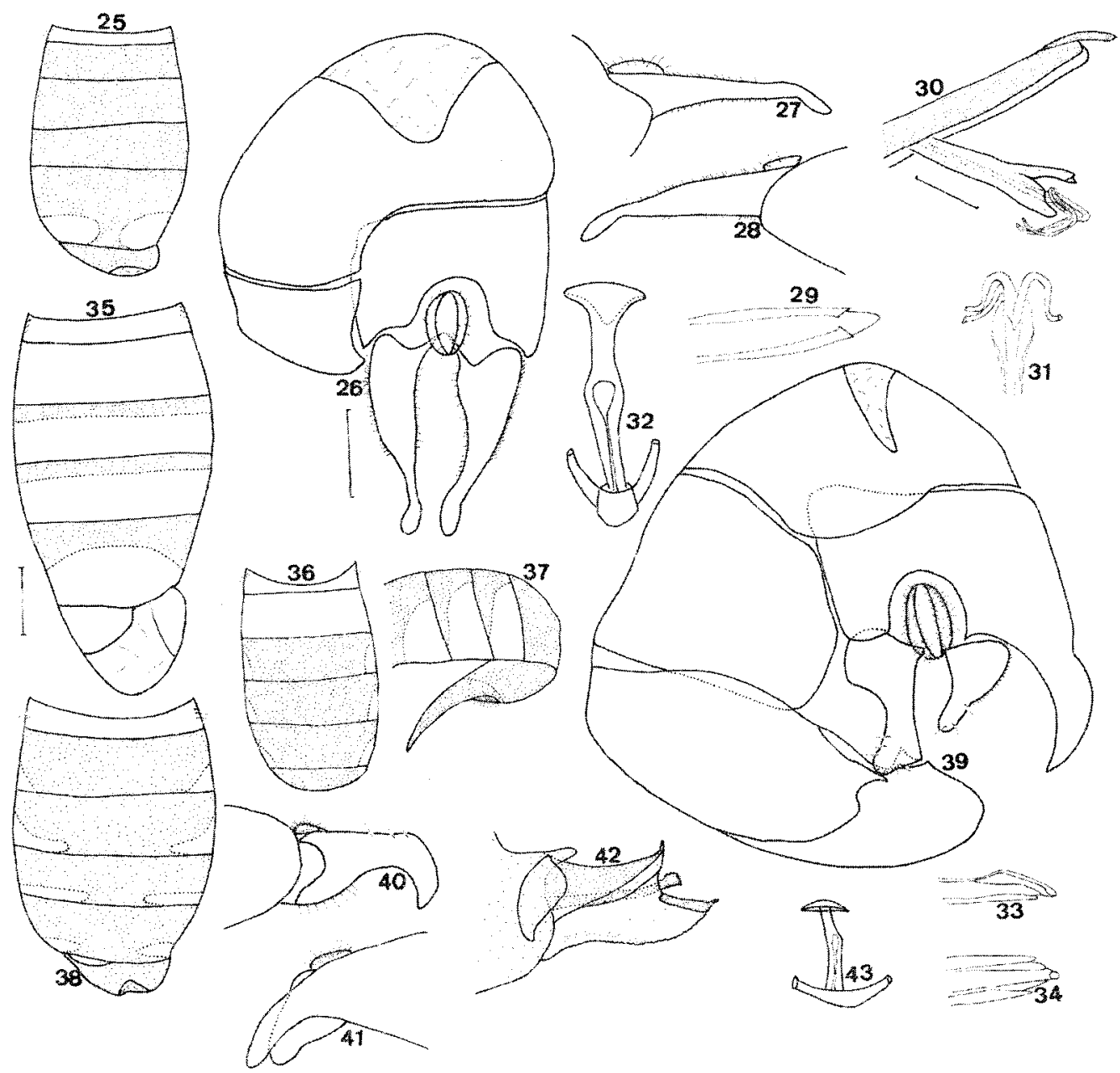

Figs. 25-32. Cephalosphaera (C.) zumbadoi ht M: 25 abdomen dv; 26 terminalia; 27 inner surstylus $1 v$; 28 outer surstylus lv; 29 paramere vv; 30 paramere and aedeagus lv; 31 aedeagus vv; 32 ejaculatory apodeme. 33-34 C. (C.) macroctenia: 33 paramere Iv; 34 idem vv. $35-37$ C. (C.) jamaicensis: 35 male abdomen dv; 36 female abdomen dv; 37 female terminalia lv. 38-43 Eudorylas abnormalis ht M: 38 abdomen dv; 39 terminalia; 40 inner surstylus 1v; 41 outer surstylus Iv; 42 paramere and aedeagus Iv; 43 ejaculatory apodeme. Scales: $0.5 \mathrm{~mm}$; figs. 25, 35-38; $0.2 \mathrm{~mm}$ : 26-28, 39-41;0.1 mm: 29-34, 42-43.

with a row of small spines in the sperm sac (Fig. 50).

Female. Body length $4.5 \mathrm{~mm}$; wing 4.7 $\mathrm{mm}$. Identical to description of male, except in the following respects: frons shining black on dorsal half, gray on ventral half. Tarsomeres mainly yellow. Abdomen (Fig. 51), in dorsal view, entirely black with gray pruinosity on tergite 1 dorsally and tergites 2-6 laterally. syntergosternite $7+8$ (Fig. 52) 2.5 times shorter than ovipositor, being the latter yellow to rufous.
Material. COSTA RICA, $3 \mathrm{~km}$ NO de Nacaone, 100 $m$, P[arque] N Nacional] Barra Honda, Prov[incia] Guana[caste], 3-30 May 1993, M. Reyes, LN 239000-386000, BL CRlo01 401888 (nt M, INBio); Code 1, 18 Abr-19 May 1993, P. Rios, BL CRI001 396442 (pt F, INBio).

Etymology. The specific name refers to the row of spines on the sperm sac of the ejaculatory apodeme (from Latin echinatus = spiny).

Remarks. E. echinatus differs from ail other Neotropical species by the aedeagus having small subapical protuberance and the sperm sac with a row of small spines. 
Eudorylas falx, sp. n.

(Figs. 53-60, 124)

Diagneses. Frontal triangle brown pruinese: Antenna black, with flagellum short acute. Wing brown infuscated. Third costal section slightly longer than fourth. Legs mainly black without ventral ctenidium on hind femur and without erect posterior bristles medially on hind tibia. Syntergosternite 8 shorter than tergite 5 with membranous area. Surstylus subsymmetrical.

Description (male). Body length $4.3 \mathrm{~mm}$; wing $5.0 \mathrm{~mm}$. Eyes contiguous on frons for distance slightly greater than length of frontal triangle. Frontal triangle black, subshining medially, brown pruinose in dorsal view, black in frontal view. Face gray-brown pruinose in dorsal view. Antenna black with flagellum short acute. Thorax dark brown to black, brown pruinose. Scutum, scutellum, notopleuron, subscutellum and postpronotal lobe brown pruinose. Mesopleuron and laterotergite gray pruinose. Legs black, except trochanter-femora and femora-tibiae articulations yellow, notably on tibiae. Fore and mid tibia with inconspicuous ctenidium on anteroventral side and hind tibia without erect posterior bristles medially. Wing (Fig. 124) distinctly brown infuscated. Third costal section slightly longer than fourth; vein $\mathrm{r}-\mathrm{m}$ placed near middle of cell $\mathrm{dm}$; vein M1 sinuous; vein dm-cu slightly curved, about as long as vein CuA1. Halter black slightly yellow on stem. Abdomen (Fig. 53) dark brown to black. Tergite 1 with 5-6 lateral bristles. Tergite 1 gray-brown pruinose and tergites $2-5$ brown pruinose across posterior margins 2-5 in dorsal view; the later gray pruinose posterolaterally in lateral view. Syntergosternite 8 brown pruinose, shorter than tergite 5 , rather strongly compressed to right and with large apical membranous area. Epandrium and surstylus (Fig. 54) yellow. Surstylus subsymmetrical, the inner one slightly longer; in lateral view as in Figs. 55-56. Paramere (Fig. 57) sickle-shaped. Aedeagus (Fig. 58) apparently without rami, membranous distally and with an inconspicuous collar of small spines at apex. Ejaculatory apodeme as in Fig. 59.
Female. One female fits male description and probably belongs here. Frons shining black medially. Vein $\mathrm{r}-\mathrm{m}$ placed near basal third of cell dm. Syntergosternite $7+8$ (Fig. 60) black, ovipositor yellow, curved inward.

Material. Code 3, Sendero Catarata, 11-12 Ene 1994, M. Zumbado, \# 2666, BL CRI001 725841 (ht M, right posterior leg lost, INBio); Code 3, BL CRI001 725842 (pt M, INPA); Code 1, 22 Ago 1993, C. Moraga, \# 2322, BL CRIO01 638793 (1 F, INBio).

Etymology. From Latin Falx (= sickle) referring to the shape of the paramere.

Remarks. E. falx is similar to E. devius (Hardy), from Argentina, in the coloration, shape of antenna, abdominal pattern and aedeagus apparently without rami. It differs by having no erect posterior bristle on the hind tibia and by the sickle-shaped paramere.

\section{Eudorylas moragai, sp. $\mathrm{n}$.}

(Figs. 61-68, 125)

Diagnoses. Scape and pedicel dark brown, flagellum yellow with apex acute. Third costal section 1.5 times longer than fourth. Postpronotal lobe and legs yellow. Surstylus downcurved distally. Aedeagus with trifid recurved lateral process. Syntergosternite 8 black, brown pruinose, with large membranous area almost dividing the segment ventrally.

Description (male). Body length $4.1 \mathrm{~mm}$; wing $5.1 \mathrm{~mm}$. Eyes contiguous on frons for a distance slightly greater than length of frontal triangle. Frontal triangle black, sparsely gray pruinose in dorsal view. Face gray pruinose in dorsal view. Antenna with scape and pedicel brown, flagellum yellow with apex long acute. Thorax dark brown to black, entirely pruinose. Legs yellow, except coxae black and fifth tarsomere brown. All femora with ventral ctenidium, inconspicuous on hind pair. Tibiae without apical bristles and hind tibia without erect posterior bristles. Wing (Fig. 125) with third costal section 1.5 times as long as fourth; vein r-m placed near basal two fifth of cell dm; vein M1 sinuous; vein dm-cu slightly curved and slightly about as long as vein CuA1. Halter yellow. Abdomen (Fig. 61) dark brown to black, brown pruinose, except tergite 1 entirely gray pruinose and tergites 2-5 gray pruinose posterolaterally, 
with larger spots on tergite 5 . Syntergosternite 8 brown pruinose, about equal to the length of tergite 5, with large membranous area dividing the segment ventrally (Fig. 62). Epandrium and surstylus dark brown to black. Surstylus asymmetrical; in lateral view downcurved (Figs. 63-64). Paramere and aedeagus as in Fig. 65. Aedeagus with a recurved trifid dorsal process. Ejaculatory apodeme as in Fig. 66.

Female. Body length $4.0 \mathrm{~mm}$; wing 5.0 $\mathrm{mm}$. Identical to male description, except in the following respects: frons shining black on upper two third and gray on ventral third. Abdomen (Fig. 67) gray pruinose on tergites 1-2 and laterally and posterolaterally on tergites $3-$ 5. Syntergosternite $7+8$ (Fig. 68) brown dorsally, yellow ventrally, with distinct ventral protuberance and slightly shorter than the yellow and straight ovipositor.

Material. Code 1, C. Moraga, \# 2563, BL CRI001 828761 (ht M, anterior pair of legs lost, INBio); Code 1, Jun 1994, P. Rios, \# 2996, B L CRI001 883791 (pt F, INBio); Code 1, \#2560, BL CRI001 818550 (pt F, INBio); Code 1, May 1994, P. Rios, Malaise, \# 2896, BL CRI001 878226 (pt F, INPA); Code 1, BL CRI001 878228 (pt F, INBio).

Etymology. The specific name is in honor of Mr. C. Moraga, who collected the specimens described here.

Remarks. E. moragai belongs to the group of species with a lateral processes on the aedeagus. It is near E. serratus described below but differs by the shape of the paramere, the aedeagus has a dorsal process that is trifid and recurved and the surstyli are more distinctly downcurved, notably the outer surstylus.

\section{Eudorylas serratus, sp. n.}

(Figs. 69-78, 126)

Diagnoses. Scape and pedicel dark brown to black, flagellum yellow with apex subfiliform. Third costal section near two times longer than fourth. Legs mainly yellow. Surstylus downcurved distally. Lateral process of aedeagus serrated.

Description (male). Body length $4.2 \mathrm{~mm}$; wing $5.0 \mathrm{~mm}$. Eyes contiguous on frons for a distance that is twice the length of frontal triangle. Frontal triangle brown pruinose in dorsal view. Face gray pruinose in dorsal view. Scape and pedicel brown to black, flagellum yellow with apex subfiliform. Thorax dark brown to black, brown pruinose, except laterotergite and scutellum gray pruinose. Scutellum with inconspicuous bristles. Legs yellow, except coxae brown. All femora with ventral ctenidium, inconspicuous on hind pair. Tibiae without distinct bristles either apically or medially. Wing (Fig. 126) with third costal section nearly 2.0 times longer than fourth; vein M1 slightly sinuous; vein dm-cu slightly curved, about as long as vein $\mathrm{CuA} 1$; vein A1 short. Halter with stem yellow, knob brown. Abdomen (Fig. 69) dark brown to black, brown pruinose, except tergite 1 entirely gray pruinose and tergites $2-5$ gray pruinose posterolaterally, more extensive on tergite 5 . Syntergosternite 8 brown pruinose, about equal to the length of tergite 5 , with ventral membranous area at right. Epandrium and surstylus (Fig. 70) brown. Surstylus downcurved in lateral view (Figs. 71, 72). Paramere as in Fig. 73. Aedeagus (Fig. 74) with serrated lateral process. Ejaculatory apodeme as in Fig. 76.

Female. Body length $3.9 \mathrm{~mm}$; wing 4.3 mm. Frons gray pruinose. Abdomen (Fig. 77) gray pruinose on tergites 1-2, except tergite 2 posteriorly brown pruinose; all tergites gray pruinose posterolaterally. Syntergosternite $7+8$ and ovipositor (Fig. 78) brown, the latter curved inward, 1.2 times greater than syntergosternite. In others respects identical to description of male.

Material. Code 1, Jul 1994, C. Moraga, \# 3158, BL CRI002 001368 (ht M, right wing lost, INBio); Code 1, 22 Ago 1993, \# 2322, BL CRI001 638791 (pt F, INBio); May 1994, P. Rios, Malaise, \# 2896, BL CRI001 878489 (pt F, INPA).

Etymology. The specific name refers to the lateral process of the aedeagus which is toothed like a saw (from Latin serra = saw).

Remarks. E. serratus belongs to the group of species with a lateral process on the aedeagus. It is near E. moragai described above. It differs by having a simple paramere, the lateral process of aedeagus toothed like a saw and the surstylus less downcurved. 

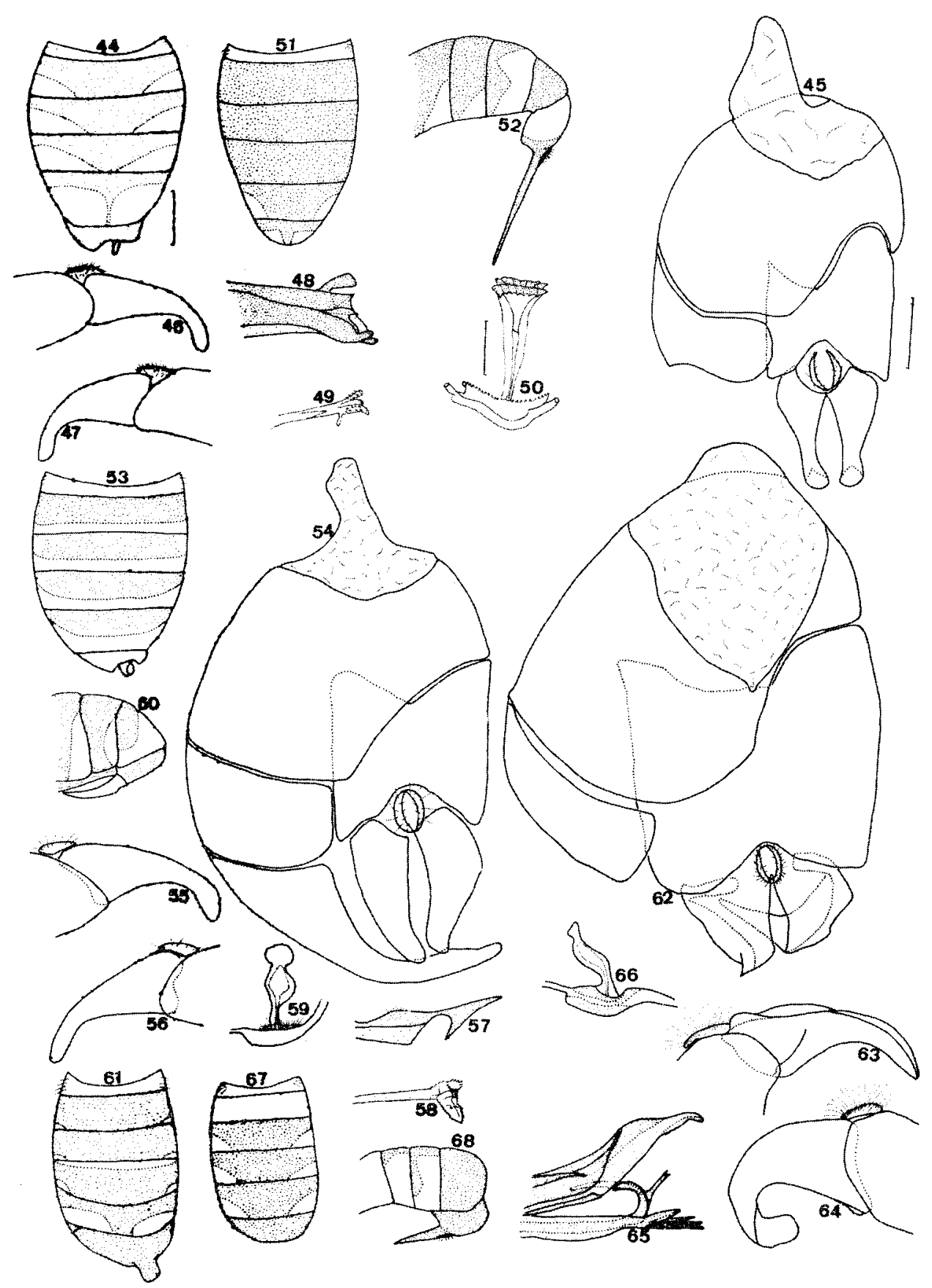

Figs. 44-52. Eudorylas echinatus he M (except figs 51-52 pt F): 44 abdomen dv; 45 terminalia; 46 inner surstylus lv; 47 outer surstylus lv; 48 paramere $1 v ; 49$ aedeagus lv; 50 ejaculatory apodeme; 51 female abdomen dv; 52 terminalia lv. 53-60 E. falx ht M (except fig. 60 pt F): 53 abdomen dv; 54 terminalia; 55 inner surstylus lv; 56 outer surstylus lv; 57 paramere; 58 aedeagus; 59 ejaculatory apodeme; 60 female terminalia. 61-68 E. mo ragai ht $\mathrm{M}$ (except figs 67-68 pt F): 61 abdomen dv; 62 terminalia; 63 inner surstylus lv; 64 outer sursty lus lv; 65 paramere and aedeagus lv; 66 ejaculatory apodeme; $67 \mathrm{fe}$ male abdomen dv; 68 terminalia Iv. Scales: $0.5 \mathrm{~mm}$ : figs. 44, 51-53, 60-61, 67-68; 0.2 mm: 45-47, 54-56, 62-64; $0.1 \mathrm{~mm}$ : $48-50,57-59,65-66$. 
Eudorylas vidali Rafael 222.

Eudorylas vidali Rafael, 1995: 831, figs. 172-176,

One specimen fits the description of this species described from Brazil and Trinidad (Rafael, 1995).

Material. COSTA RICA, F[in]ca Cafrosa, Est[ación] las Mellizas, P[arque] N[acional] Amistad, Prov[incia] Punta[renas], M. Ramirez, Abr 1991, LS 316100-596100, BL CRI000 292421 (1 M, INBio).

\section{Eudorylas willistoni (Kertész)}

Pipunculus willistoni Kertész, 1900: 244 (n. n. for aculeatus Williston, 1892: 88, preocc. Loew 1858).

This species has been previously recorded from Costa Rica (De Meyer, 1996) but it was not represented in the examined material.

\section{Eudorylas spp}

Fourteen specimens could not be associated with males and seem to belong to many different species. All specimens are deposited at INBio.

\section{Genus Basileunculus Rafael}

This genus was revised and keyed by Rafael (1987). It probably occurs in the Nearctic Region. This is the first record from Costa Rica.

\section{Basileunculus rex (Curran) \\ Pipunculus rex Curran, 1934: 416.}

This species was re-characterized by Rafael (1987). Three specimens are referred to $B$. rex. This species has already been recorded from Brazil and Guyana (De Meyer, 1996).

Material. COSTA RICA, Rancho Quemado, $200 \mathrm{~m}$, Peninsula de Osa, Prov[incia] Puntarenas, K. Flores, Abr 1992, LS 292500-511000, BL CRI000 773514 (1 M, NBio); BL CRI000 773502 (1 F, INBio); Est[acion] S[an]ta Rosa, 300 m, P[arque] N[acional] Santa Rosa, Prov[incia] Guanacaste, M. A. Zumbado, Ene 1991, LN 313000359800, BL CRI000 793355 (1 F, INPA).

\section{Genus Metadorylas Rafael}

The Neotropical species were revised and keyed by Rafael (1990b). This genus is limited to the New World. It is best known in the Neotropical Region. Here it is represented by only one species.

\section{Metadorylas spinosus (Hardy)}

Dorylas (Eudorylas) spinosus Hardy, 1948a: 4.

One specimen is referred to this species which has been recorded in the Neotropical Region from widespread localities, Mexico, Costa Rica, Grenada, Trinidad, Colombia, Ecuador, Brazil and Argentina (De Meyer, 1996).

Material. COSTA RICA, Bosque Esquinas, Pen[insula] Osa, Prov[incia] Punta[renas], 200 m, Mar 1994, M. Segura, LS 301400-542200, \# 2776, B L CRI001 758100 (1 M, INBio).

\section{Genus Elmohardyia Rafael}

Elmohardyia was revised by Rafael (1988b) and it is well represented in Costa Rican material with five new species and at least three more species represented only by unidentified females. Two species have been previously recorded from Costa Rica.

\section{Elmohardyia adunca, sp. n.}

(Figs. 79-85, 127)

Diagnoses. Scape and pedicel dark brown to black, flagellum yellow. Third costal section about as long as fourth. Abdomen entirely gray pruinose on tergites 1 and 2 and posterolaterally on tergites $3-5$. Syntergosternite 8 without membranous area. Inner surstylus strongly curved inward, longer than outer surstylus.

Description (male only, female unknown). Body length $4.5 \mathrm{~mm}$; wing $4.7 \mathrm{~mm}$. Eyes narrowly dichoptic. Frontal triangle and face with gray pruinosity. Scape and pedicel dark brown to black, flagellum yellow. Scutum and scutellum dark brown to black, brown pruinose. Notopleuron, postpronotal lobe, mesopleuron and small part of scutellum gray pruinose. Scutellum with inconspicuous bristles. Legs yellow, except coxae black, all femora largely dark discolored and distal tarsomeres brown. Wing (Fig. 127) with third costal section as long as fourth; vein r-m placed near basal third of cell $\mathrm{dm}$. Halter with stem yellow, knob black. Abdomen (Fig. 79) dark brown to black, subshining, gray pruinose on tergite 1 and 2 and posterolaterally on tergites $3-5$; tergite 1 with 34 small bristles laterally. Syntergosternite 8 


\section{Key to recorded Costa Rican species of Elmohardyia (males)}

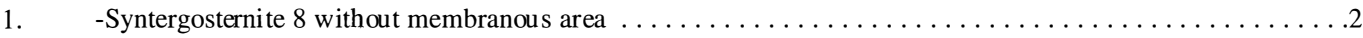

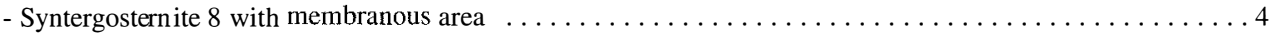

2. -Tergites 4 and 5 largely silvery gray pruinose (Fig. 110). Antenna and legs mainly black. Terminal ia as in Fig. 111.

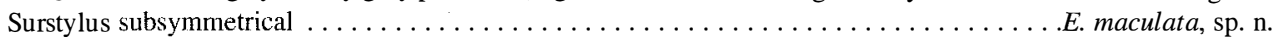
- Tergites 4 and 5 only with posterolateral spots of gray pruinescence. Flagellum and legs mainly yellow. Inner surstylus extremely well developed, rather $\mathrm{C}$-shaped (Figs. 80, 96) $\ldots \ldots \ldots \ldots$

3. -Inner surstylus strongly downcurved in lateral view (Fig. 81) . . . . . . . . . . . . . . E. adunca, sp. n

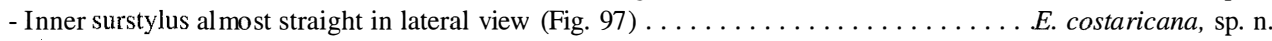

4. $\quad$-Inner surstylus with apex rather outwardly curved (Fig. 97) $\ldots \ldots \ldots \ldots$

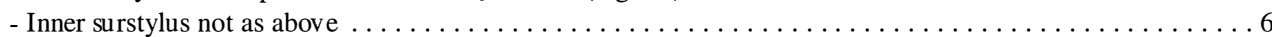

5. -Inner surstylus with internal median sinus (Fig. 87). Outer gonopod shorter than paramere (Fig. 90) . . . . . .

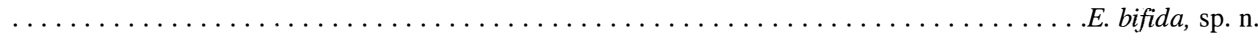
- Inner surstylus with internal basal sinus. Outer gonopod longer than paramere

E. gowdeyi (Curran)

6. -Inner surstylus straight. Tergites 3-5 with posterolateral gray pruinescence spots. Third costal section greater than fourth $\ldots \ldots \ldots \ldots \ldots \ldots \ldots \ldots \ldots \ldots \ldots \ldots \ldots \ldots \ldots \ldots$ arnaudi -Inner surstylus distinctly C-shaped inwardly (Fig. 105). Only tergite 5 with posterolateral gray pruinose spots.

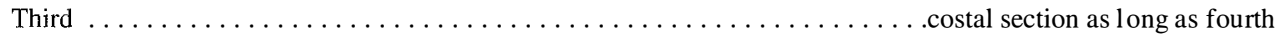

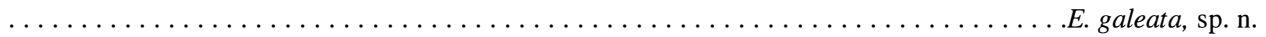

black, longer than tergite 5, without membranous area. Epandrium and surstylus (Fig. 80) yellow. Surstylus asymmetrical, the inner strongly curved in and downward, longer than outer surstylus; in lateral view as in Figs. 8182. Paramere as in Fig. 83. Aedeagus as in Fig. 84. Ejaculatory apodeme as in Fig. 85.

Material. Code 2, Feb 1994, Z. Fuentes, \# 2615, BL CRI001 962298 (ht M, INBio).

Etymology. The specific name refers to thie inner surstylus strongly inwardly curved (from Latin aduncus = bent inward).

Remarks. E. adunca is near E. costaricana described below and both belong to the group without membranous area on syntegosternite 8. E. adunca is different by the shape of the inner surstylus which is strongly downcurved in lateral view and by having simple paramere, while $E$. costaricana has the inner surstylus almost straight in lateral view and more complex paramere.

\section{Elmohardyia arnaudi Rafael}

Elmohardyia arnaudi Raf ael, 1988b: 229.

This species was described originally from Mexico and Costa Rica. It was not represented in the studied material.
Elmohardyia bifida, sp. n.

(Figs. 86-94, 128)

Diagnoses. Scape and pedicel dark brown to black. Legs yellow. Abdomen with gray pruinosity on tergite 1 , on basal half of tergite 2 and posterolaterally on tergites 4 and 5. Syntergosternite 8 with distal membranous area on the right. Epandrium and surstylus brown. Surstylus asymmetrical, the inner being slightly curved outward.

Description (male). Body length $4.9 \mathrm{~mm}$; wing $5.7 \mathrm{~mm}$. Junction of compound eyes slightly shorter than length of frontal triangle. Frons and face pruinose. Scape and pedicel black, flagellum lost. Scutum, scutellum and subscutellum dark brown to black, brown pruinose. Postpronotal lobe sparsely gray pruinose. Notopleuron partially gray pruinose in certain light. Mesopleuron gray pruinose. Legs yellow, except coxae black and tarsomeres dark brown to black. Wing (Fig. 128) with third costal section about as long as fourth; vein r-m placed near basal third of cell dm. Halter with stem yellow, knob black. Abdomen (Fig. 86) black, subshining, gray pruinose on tergite 1 , on basal half of tergite 2 and posterolaterally 

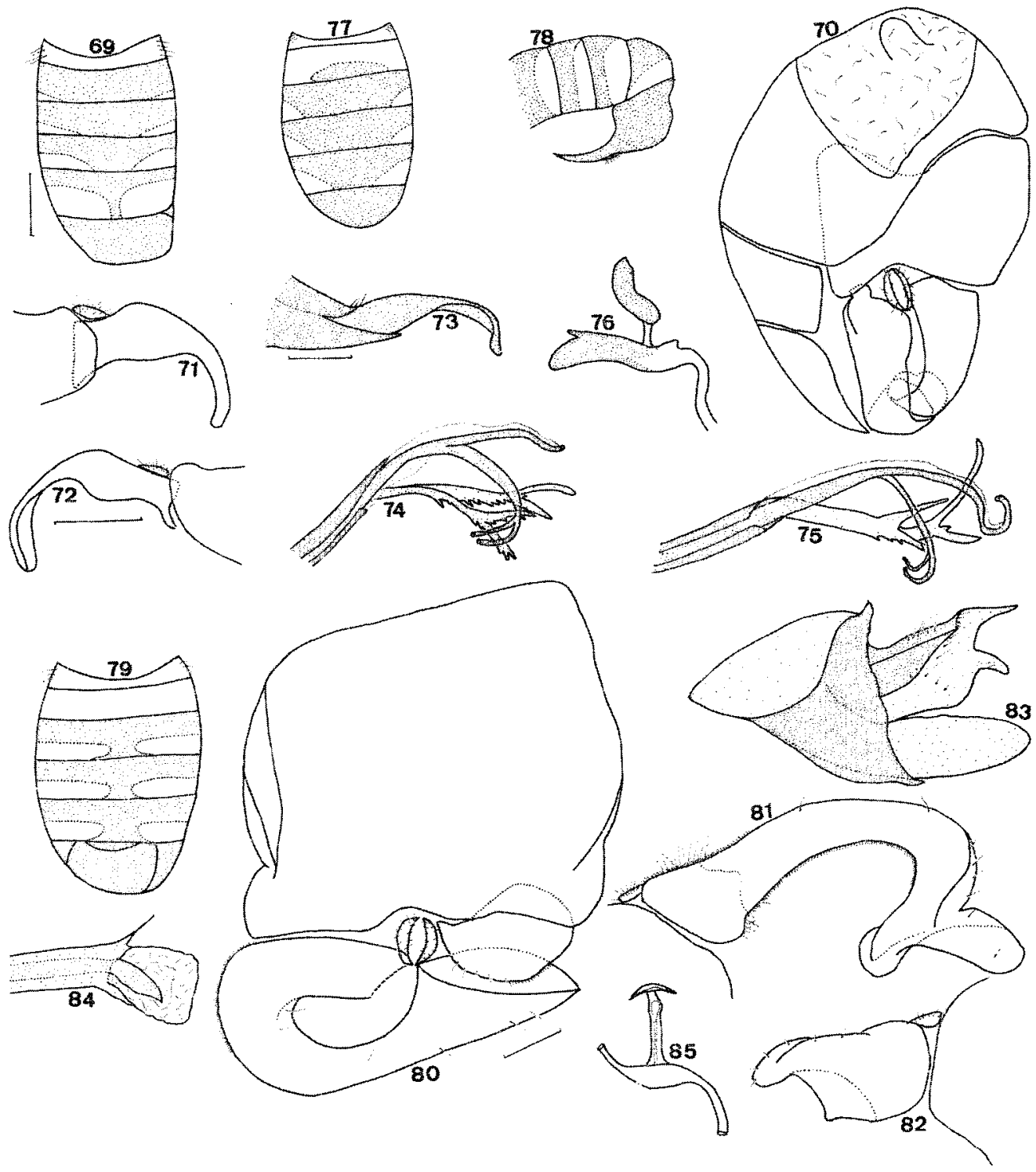

Figs. 69-78. Eudorylas serratus ht M (except figs 77-78 pt F): 69 abdomen dv; 70 terminalia; 71 inner surstylus lv; 72 outer surstylus lv; 73 paramere lv; 74 aedeagus lv; 75 idem vv; 76 ejaculatory apodeme; 77 female abdomen dv; 78 terminalia lv. 79-85 Elmoha nd yia adunca ht M: 79 abdomen dv; 80 terminalia; 81 inner surstylus lv; 82 outer surstylus lv; 83 paramere lv; 84 aedeagus; 85 ejaculatory apodeme. Scales: $0.5 \mathrm{~mm}$ : figs 69, 77-79; $0.2 \mathrm{~mm}$ : 70-72, 80-82; $0.1 \mathrm{~mm}$ : 73-76,

on tergites $4-5$, more extensive on the later. Syntergosternite 8 slightly larger than tergite 5 , with membranous area on the right. Epandrium and surstylus (Fig. 87) brown. Surstylus asymmetrical, the inner 1.3 times longer than outer surstylus; in lateral view as in Figs. 8889. Paramere (Fig. 90) with a dorsal process that is bifid at apex. Aedeagus as in Fig. 91. Ejaculatory apodeme as in Fig. 92.

Female. Body length $4.4 \mathrm{~mm}$; wing 5.4 $\mathrm{mm}$. Scape and pedicel black, flagellum yellow. Frons entirely silvery gray pruinose. Abdomen with the same pruinosity pattern as in male, also without spots of gray pruinosity on 
tergite 3 . In others respects identical to the male description. Abdomen (Fig. 93). Tergite 6 (Fig. 94) dark brown to black, gray pruinose posterolaterally and with median dorsal sulcus. Syntergosternite $7+8$ dark brown to black, shorter than the yellow to rufous ovipositor.

Material. Code 3, 10 Ene 1994, M. Zumbado, \# 2665, BL CRI001 725723 (ht M, INBio); Code 1, 21 Mar-06 Abr 1993, C. Moraga, BL CRI001 391164 (pt F, INBio); Jul 1994, \# 3158, BL CRI002 001387 (pt F, headless, INBio); Ene 1994, \# 2563, BLCRI001 828793 (pt F, INPA).

Etymology. The specific name refers to the bifurcation at the apex of the dorsal process of the paramere in the male terminalia (from Latin bifidus $=$ bifurcated.

Remarks. E. bifida differs from other Neotropical species by tergite 2 gray pruinose on its basal half, inner sürstylus rather outwardly curved and particularly by the dorsal process of the paramere which is bifid at the apex.

\section{Elmohardyia costaricana, sp. n.} (Figs. 95-103, 129)

Diagnoses. Scape and pedicel dark brown to black. Legs mainly yellow. Abdomen dark brown to black, subshining. Tergites 1 and 2 largely gray pruinose and tergites 3-5 gray pruinose posterolaterally. Syntergosternite 8 without membranous area.

Description (male). Wing $5.0 \mathrm{~mm}$. Eyes contiguous on frons for a short distance. Frontal triangle greasy (probably gray pruinose). Face gray pruinose. Scape and pedicel dark brown to black (flagellum lost). Scutum and scutellum dark brown to black, brown pruinose. Notopleuron, postpronotal lobe, anepisternun, mesopleuron, subscutellum and laterotergite gray pruinose. Scutellum with inconspicuous bristles. Legs yellow, except coxae black, femora slightly dark discolored medially and distal tarsomeres dark brown to black. Wing (Fig. 129) with third costal section about as long as fourth; vein r-m placed near basal third of cell dm. Halter with stem yellow, knob black. Abdomen (Fig. 95) dark brown to black, subshining, gray pruinose on tergite 1 , most of tergite 2 and posterolaterally on tergites 3-5, with larger spots on tergite 5. Tergite 1 with small bristles laterally. Syntergosternite 8 as long as tergite 5, without membranous area. Epandrium and surstylus (Fig. 96) brown. Surstylus asymmetrical, the inner inwardly curved and longer than outer surstylus; in lateral view as in Figs. 97-98. Paramere as in Fig. 99. Aedeagus as in Fig. 100. Ejaculatory apodeme as in Fig. 101.

Female. Body length $4.3 \mathrm{~mm}$; Wing 5.0 $\mathrm{mm}$. Scape and pedicel black, flagellum yellow. Frons and face silvery gray pruinose. Abdomen (Fig. 102) with larger gray pruinosity on tergites 3-6. In other respects identical to the male description. Syntergosternite 7+8 (Fig. 103) black dorsally, rufous ventrally, as long as the straight rufous colored ovipositor.

Material. Code 1, Jul 1994, C. Moraga, \# 3158, BL CRI002 001502 (ht M, INBio: head lost af ter description; flagellum and right wing 1ost); 21 Mar-07 Abr 1993, P. Rios, BL CRI001 828807 (pt F, INBio).

Etymology. The specific name refers to the country Costa Rica.

Remarks. See remarks under E. adunca described above.

\section{Elmohardyia galeata, sp. n.}

(Figs. 104-109, 130)

Diagnoses. Scape and pedicel black, flagellum yellow. Third costal section as long as fourth. Legs yellow. Tergite 5 with gray pruinosity posterolaterally. Inner surstylus strongly curved inward, about two times longer than outer surstylus.

Description (Male only, female unknown). Body length $4.9 \mathrm{~mm}$; wing $5.5 \mathrm{~mm}$. Eyes contiguous on frons for short distance. Scape and pedicel black, flagellum yellow. Frontal triangle and face silvery gray pruinose. Scutum and scutellum dark brown to black, brown pruinose. Notopleuron partially gray pruinose under certain lights. Postpronotal lobe and mesopleuron gray pruinose. Scutellum with inconspicuous bristles. Subscutellum brown, sparsely brown pruinose. Legs yellow, except coxae black, femora slightly brown medially and last tarsomeres black. Wing (Fig. 130) with third costal section as long as fourth; vein r-m placed near basal third of cell dm. Halter with stem yellow, knob brown. Abdomen (Fig. 104) dark brown to black, subshining, brown pruinose, 

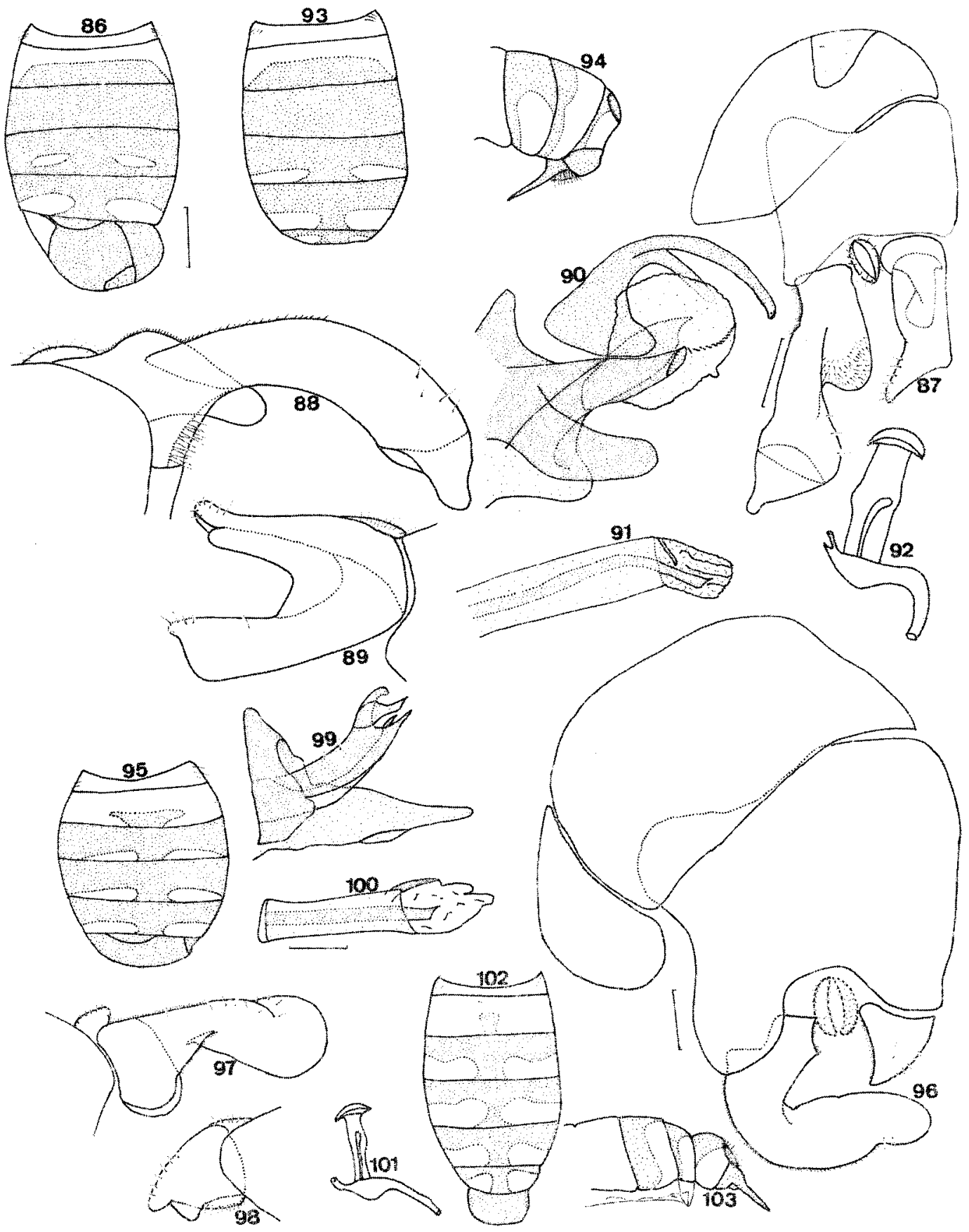

Figs. 86-94. Elmoha rdyia bifida ht M (except figs $93-94$ pt F): 86 abdomen dv; 87 terminalia; 88 inner surstylus lv; 89 outer surstylus lv; 90 paramere lv; 91 aedeagus lv; 92 ejaculatory apodeme; 93 female abdomen; 94 terminalia lv. 95-103 E. costaricana ht M (except figs. 102-103 pt F): 95 abdomen dv; 96 ter minalia; 97 inner surstylus lv; 98 outer surstylus lv; 99 paramere Iv; 100 aedeagus lv; 101 ejaculat ory apodeme; 102 female abdomen; 103 terminalia lv. Scales: $0.5 \mathrm{~mm}$ : figs 86, 93-95, 102-103; $0.3 \mathrm{~mm}$ : 87; $0.2 \mathrm{~mm}$ : 88-89, 96-98; $0.1 \mathrm{~mm}:$ 90-92, 99-101. 


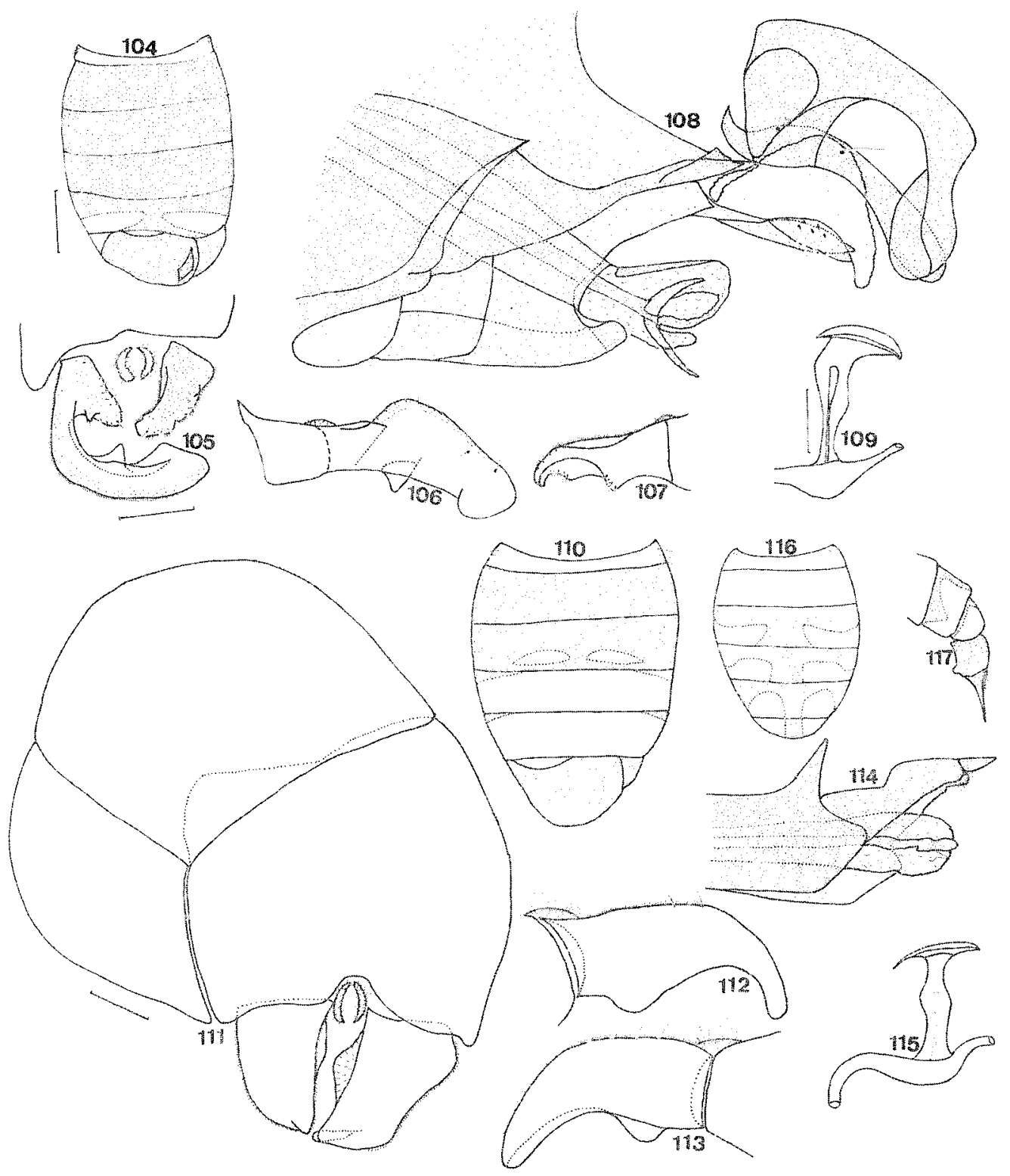

Figs. 104-109. Elmohardyia galeata ht M: 104 abdomen dv; 105 terminalia; 106 inner surstylus lv; 107 outer surstylus lv; 108 paramere and aedeagus Iv; 109 ejaculatory apodeme. 110-117 E. maculata ht M (except figs. 116-117 pt F): 110 abdomen dv; 111 terminalia; 112 inner surstylus lv; 113 outer surstylus Iv; 114 paramere and aedeagus lv; 115 ejaculatory apodeme; 116 female abdomen; 117 terminalia lv. Scales: $0.5 \mathrm{~mm}$ : figs 104, 110, 116-117;0.3 mm: 105-107;0.2 mm: 111-113: 0.1 mm: 108-109, 114-115.

except on tergite 1 and posterolaterally on tergite 5 gray pruinose; tergite 1 with 2-3 lateral bristles. Syntergosternite 8 slightly longer than tergite 5 , with membranous area on the right.
Epandrium and surstylus yellow. Surstylus (Fig. 105) asymmetrical, the inner strongly curved inwardly, more than two times longer than outer surstylus; in lateral view as in Figs. 

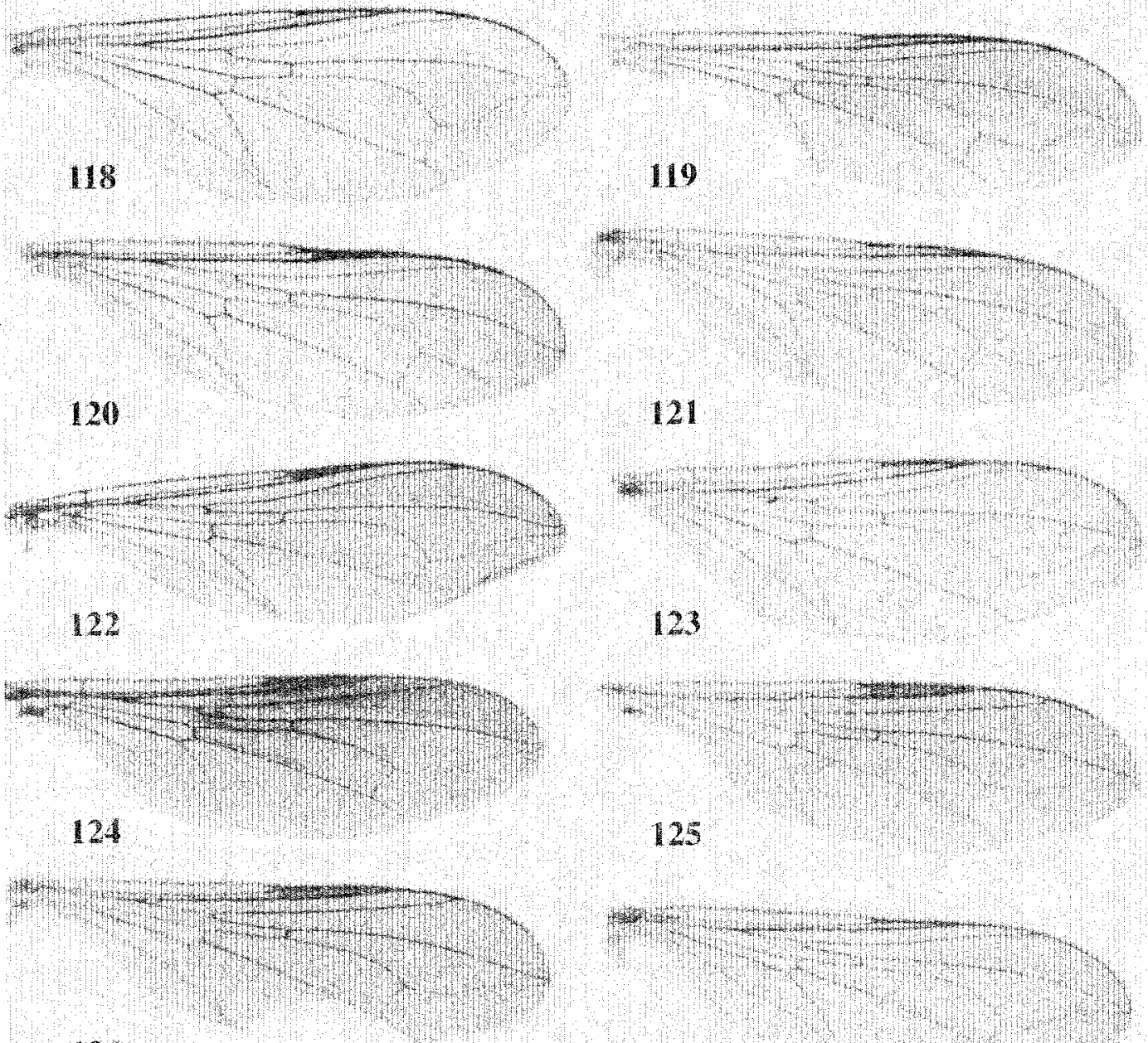

126
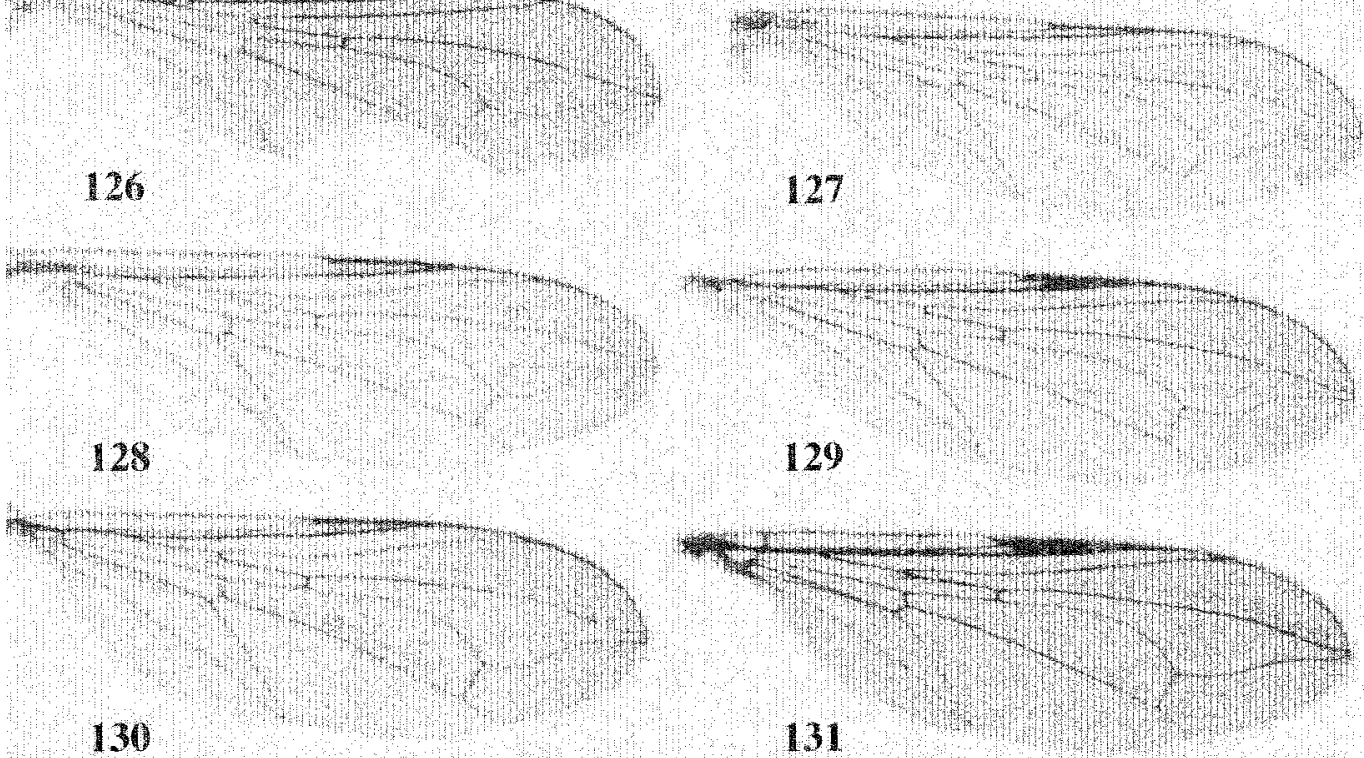

Figs. 118-131. Holotype wings. 118 Parapipunculus elegantulus; 119 Cephalosphaera $(C$.$) guanacastensis; 120$ C. (C.) procera; 121 C. (C.) zumbadoi; 122 Eudorylas abnormalis; 123 E. echinatus; 124 E. falx; 125 E. moragai; 126 E. serratus; 127 Elmohardyia adunca; 128 E. bifida; 129 E. costaricana; 130 E. galeata; 131 E. maculata. 
106-107. Paramere and aedeagus as in Fig. 108. Apex of paramere with complex hat-like structure. Ejaculatory apodeme as in Fig. 109.

Material. Code 1, 22 Ago 1993, C. Moraga, \# 2322, BL CRI001 638403 (ht M, INBio); Apr 1994, \# 2841, BL CRI001 789257 (pt M, headless, INPA).

Etymology. The specific name refers to the hat-like structure at the apex of the paramere (from Latin galea $=$ helmet).

Remarks. E. galeata has a hat-like structure at the apex of paramere and it is closely related to E. arx Rafael and E. merga Rafael, both from Peru. It differs from other Peruvian species by long and strongly inwardly curved inner surstylus and by having only tergite 5 with dorsal gray pruinosity (inner surstylus not inner curved and at least, tergites 3-5 with dorsal spots of gray pruinosity in both Peruvian species).

\section{Elmohardyia gowdeyi (Curran)}

Pipunculus gowdeyi Curran, 1928: 36.

This species was described from a female specimen from Jamaica which was studied by Rafael (1988b) and in the same paper a male believed to be conspecific was described from Guyana. In the examined material two Costa Rican females are conspecific and referred to E. gowdeyi. No male was examined and Rafael's association could not be confirmed. The specimens are deposited at INBio.

\section{Elmohardyia maculata, sp. n.}

(Figs. 110-117, 131)

Diagnoses. Antenna black. Legs black, except apices of femora and bases of tibiae yellow. Tergites 4 and 5 largely silvery gray pruinose. Syntergosternite 8 longer than tergite 5 , without membranous area.

Description (male). Body length $5.0 \mathrm{~mm}$; wing $5.9 \mathrm{~mm}$. Eyes contiguous on frons for a distance equal to length of the frontal triangle. Frontal triangle brown pruinose in dorsal view. Face gray pruinose. Antenna black. Scutum and scutellum dark brown to black, brown pruinose. Notopleuron and postpronotal lobe partially gray pruinose. Subscutellum brown pruinose. Mesopleuron and laterotergite gray pruinose. Scutellum with inconspicuous bris- tles. Legs black, except apices of femora and bases of tibiae yellow. Wing (Fig. 131) with third costal section 1.2 times as long as fourth; vein $\mathrm{r}-\mathrm{m}$ placed near basal third of cell $\mathrm{dm}$. Halter black. Abdomen (Fig. 110) dark brown to black, sub-shining with gray pruinosity on tergite 1 , posterodorsally on tergite 3 and on all extension of tergites 4-5, except anterolaterally brown pruinose. Tergite 6 gray pruinose. Syntergosternite 8 dark brown to black, 1.3 times longer than tergite 5 , without membranous area. Epandrium and surstylus black. Surstylus (Fig. 111) subsymmetrical, the inner slightly shorter, both with apex slightly curved downward. In lateral view as in Figs. 112-113. Paramere and aedeagus as in Fig. 114. Aedeagus without subapical spicula. Ejaculatory apodeme as in Fig. 115.

Description (female). Wing $4.8 \mathrm{~mm}$. Head lost. Third costal section as long as fourth. Abdomen (Fig. 116) gray pruinosity on tergites 1-2 and posterolaterally on tergites 3-6. Tergite 6 with median dorsal sulcus. Syntergosternite $7+8$ dark brown to black, with median dorsal sulcus and about equal to length of the rufous and straight ovipositor (Fig. 117). In other respects identical to the male description.

Material. Code 2, Feb 1994, Z. Fuentes, \# 2615, BL CRI001 962374 (ht M, INBio); Code 1, 22 Ago 1993, C. Moraga, \# 2322, BL CRI001 638724 (pt F, INBio).

Etymology. The specific name refers to the gray pruinosity pattern on the abdomen (from Latin macula = spot, mark).

Remarks. E. maculata belongs to the group of species without membranous area on syntergosternite 8 . It differs by tergites 4 and 5 being almost entirely silvery gray pruinose, by the structure of the surstylus and paramere and the absence of a spicula on the aedeagus.

\section{Elmohardyia spp.}

Five female specimens representing three different species cannot be identified and were not associated with any males. They present different coloration patterns on antennae, legs, abdomens and the ovipositors. All specimens are deposited at INBio. 


\section{Genus Tomosvaryella Aczél}

The species from Mexico, Central America and the West Indies were revised and keyed by Ale-Rocha \& Rafael (1995). The West Indian species were keyed by Rafael (1996). Three species have been recorded in Costa Rica.

\section{Tomosvaryella lynchi (Shannon)}

Pipunculus lynchi Shannon, 1927: 38.

This species is widespread across New World, occurring from USA to Argentina (De Meyer, 1996).

Material. Code 1, Abr 1994, P. Rios, \# 2844, BL CRI001 794473 (1 M, INBio); COSTA RICA, Estac[ión] Mengo, $1100 \mathrm{~m}$, SW side Volcan Cacao, Guanac[aste], Feb 1989, GNP Biodiversity Survey, 852810W-105543N, BL CRI001 053950 (1 M, INPA).

\section{Tomosvaryella subvirescens (Loew)}

Pipunculus subvirescens Loew, 1872: 87.

This species is cosmopolitan and it has previously been recorded from Costa Rica (Aczél, 1952; De Meyer, 1996).

\section{Tomosvaryella tuberculata Hardy}

Tomosvaryella tuberculata Hardy, 1948a: 11.

This species is widespread across Central America and the West Indies and it has also previously been recorded from Costa Rica (Ale-Rocha \& Rafael, 1995).

\section{Tomosvaryella spp}

Three female specimens representing apparently the same species were not associated with males and cannot be identified.

All specimens are deposited at INBio.

\section{ACKNOWLEDGMENTS}

We extend our sincere thanks to Manuel Zumbado, INBio, for the opportunity to study the Costa Rican pipunculids and to the Costa Rican parataxonomists for their valuable contribution to global scientific knowledge and natural resources conservation through their collective efforts in the Conservation Areas. In addition, we are grateful to D. M. Wood (CNC) and J. R. Vockeroth (CNC) who offered valuable com- ments on the manuscript. The senior author is Fellow of the Conselho Nacional de Desenvolvimento Científico e Tecnológico, CNPq, Brazil.

\section{RESUMEN}

Se informa de la presencia de veintinueve especi s y diez géneros de Pipunculidac en Costa Rica, con ocho especies previamente registradas, trece nuevas y ocho nuevos registros. Se describen e ilustran las seguientes especies: $\mathrm{Cep}$ halosphaera guanacastensis, C. procera, C. zumbadoi, Eudorylas abnormalis, E. echinatus, E. falx, E. moragai, E. serratus, Elmohardyia adunca, E: bifida, E. costaricana, E. galeata y E. maculata. Los nuevos registros son Chalarus connexus Rafael, Parapipunculus elegantulus (Williston), Cephalosphaera jamaicensis (Johnson), C. macroctenia Rafael, C. panamaensis Hardy, Microcephalops williamsi (Hardy), Eudorylas vidali Rafael y Basileunculus rex (Curran). Parapipunculus elegantulus (Williston) es redescrito a partir del holotipo. Se describen las hembras previamente desconocidas de P. elegantulus y C. jamaicensis. Se presenta la lista de todas las especies costarricensis y claves para las especies de Cephalosphaera Enderlein y Elmohardyia Rafael.

\section{REFERENCES}

Aczél, M. 1948. Grundlagen einer Monographie der Dorilaiden Diptera). Dorilaiden Studien VI. Acta zool. lilloana, 6: 5-198.

Aczél, M. 1952. Catalogo de la familia Dorilaidae (Pipunculidae) de la región Neotropical. Rev. Soc. ent. argent. 31(4): 237-250.

Ale-Rocha, R. \& J. A. Rafael 1995. Tomosvaryella Aczél do México, América Central e Antilhas (Diptera, Pipunculidae). Rev. bras. Zool. 12(2): 407-427.

Banks, N, 1915. Notes and description of Pipunculidae. Psyche 22: 166-170.

Boza, M. A. \& R. Mendoza 1981. The National Parks of Costa Rica. 310 pp. Madrid.

Cresson, E. T. 1911. Studies in North American Dipterology: Pipunculidae. Trans. Am. ent. Soc. 36: 267-329.

Cumming, J. M.; B. J. Sinclair \& D. M. Wood 1995. Homology and phylogenetic implications of male genitalia in Diptera-Eremoneura. Ent. scand. 26: 120-151.

Curran, C. H. 1928. Registros and descriptions of Diptera, mostly from Jamaica. In: Catalogus Insectorum Jamaicensis. Gowdey, C. C. (ed.) Ent. Bull. Dept. Agric. 4: 36 [appendix]. 
Curran, C. H. 1934. The families and genera of North American Diptera. New York, Ballou Press, 512 pp.

De Meyer, M. 1989. Systematics of Nearctic species of the genus Cephalops Fallén (Diptera, Pipunculidae). Bull. Inst. r. Sci. nat. Belg. (Ent.) 59: 99-130.

De Meyer, M. 1994. Phylogenetic relationship within the Cephalopsini (Diptera, Pipunculidae). Bull. Ann. Soc. r. belg. Ent. 130: 7-18.

De Meyer, M. 1996. World catalogue of Pipunculidae (Diptera). Studiendocumenten van Het K.B.I.N. 86: $1-127$

Gauld, I. 1997. The Ichneumonidae of Costa Rica, 2. Mem. Amer. Ent. Soc. 57: 1-478.

Gomez, L. D. 1986. Vegetación y clima de Costa Rica. 327 pp, EUED, San José.

Hardy, D. E. 1943. A revision of Nearctic Dorilaidae (Pipunculidae). Univ. Kansas Sci. Bull. 29(1): 1-231.

Hardy, D. E. 1948a. Neotropical Dorilaidae (Pipunculidae) studies, Part 1 (Diptera). Psyche 55(1): 1-15.

Hardy, D. E. 1948b. New and little known Neotropical Dorilaidae (Pipunculidae-Diptera). J. Kans. ent. Soc. 21(4): 124-133.

Hardy, D. E. 1954. Neotropical Dorilaidae studies, Part III. Brazilian species and key to the known species of Dorilas sens. lat. Bol. Mus. Nac., Zool. 123: 160 .

Hardy, D. E. 1960. Family Pipunculidae (Dorilaidae), In: Museu de Zoologia, Universidade de São Paulo. A catalogue of the Diptera of the Americas South of the United States, 45: 1-15.

Herrera, W. 1986. Clima de Costa Rica, pp: 1-118. In: Gomez, L. D. (ed.) Vegetación y Clima de Costa Rica 2 , 118 pp, San José.

Johnson, C. W. 1919. A revised list of the Diptera of Jamaica. Bull. Am. Mus. nat. Hist. 41(8): 421-449.

Kertész, K. 1900. Bemerkungen ueber Pipunculiden (Dipt.). Wien Ent. Zeit. 19: 244-245.

Loew, E. 1858. Bidrag till kännedomen om Afrikas Diptera [part.]. Öfvers. K. VetenskAkàd. Förh. Stockh. 14: 337-383.

Loew, E. 1872. Diptera Americae septentrionalis indigena. Centuria decima. Berl. Ent. Zeitschr. 16: 49-115.

McAlpine, J. F. 1981. Morphology an d terminology, pp: 963. In: Manual of Nearctic Diptera 1: 674 pp. McAlpine, J. F. et al. (eds.). Monogr. Nr 27, Res. Branch, Agriculture Canada.
Murillo, J. \& R. Zeledon 1985. Flebótomos de Costa Rica. Brenesia 23 (supl.): 1-137.

Rafael, J. A. 1986. Parapipunculus, a new genus of Pipunculidae (Diptera) from the Nearctic Region and Mexico. Revta bras. Ent. 30(2): 421-424.

Rafael, J. A. 1987. Basileunculus, um gênero novo de Pipunculidae (Diptera) da região Neotropical, com chave para as espécies. Acta Amazonica 16/17 (nr único): 627-634.

Rafael, J. A. 1988a. Pipunculidae (Diptera) da região Neotropical. I. Redescrição de Chalarus chilensis Collin, comb.n. e descricão de duas espécies novas da Amazônia. Revta bras. Zool. 5(1): 1-9.

Rafael, J. A. 1988b. Pipunculidae (Diptera) neotropicais do gênero Elmohardyia Rafael. Acta Amazonica 18(1-2): 223-264.

Rafael, J. A. 1990a. Revisão das espécies neotropicais do gênero Chalarus Walker, 1834 (Diptera: Pipunculidae). Iheringia, Sér. Zool. 70: 45-53.

Rafael, J. A. 1990b. A s espécies neotropicais de Metadorylas Rafael (Diptera: Pipunculidae). Bolm Mus. Para. Emílio,Goeldi, sér. Zool. 6(2): 127-164.

Rafael, J. A. 1991. Revisão das espécies neotropicais do gênero Cephalops Fallén (Diptera: Pipunculidae). Acta Amazonica 20 (nr único): 353-390

Rafael, J. A. 1992. Chapter 42. A review of the Neotropical species of big-headed flies, genus Cephalosphaera (Diptera, Pipunculidae), pp: 631-646. In: D. Quintero \& A. Aiello (eds.): Insects of Panama and Mesoamaerica: Selected studies, xxii + 692 pp. Oxford University Press.

Rafael, J. A. 1993. Espécies de Eudorylas Aczél (Diptera, Pipunculidae) do México e América Central. Revta bras. Ent.37(4): 751-762

Rafael, J. A. 1995. Espécies de Eudorylas Aczél (Diptera, Pipunculidae) da América do Sul. Revta bras. Ent. 39(4): 793-838.

Rafael, J. A. 1996. Pipunculidae (Insecta: Diptera) of the Dominican Republic: New records and description of new species. Ann. Carnegie Mus. 65(4): 363-381

Rafael, J.A. \& M. De Meyer, 1992. Generic classification of the family Pipunculidae (Diptera): a cladistic analysis. J. Nat. Hist. 26: 637-658.

Shannon, R. C. 1927. Some new Diptera from Argentina. Rev. Soc. ent. argent. II(4): 31- 42.

Stiles, F. G. \& A. F. Skutch, 1989. A Guide to the Birds of Costa Rica, 511 pp. Cornell Univ. Press, Ithaca.

Williston, S. W. 1892. Pipunculidae (Insecta, Diptera), 8688. In: Godman, F. D. \& O. Salvin (eds.). Biologia Centrali Americana, Zoologia. 